JURNAL SOSIAL-EKONOMI PERTANIAN DAN AGRIBISNIS

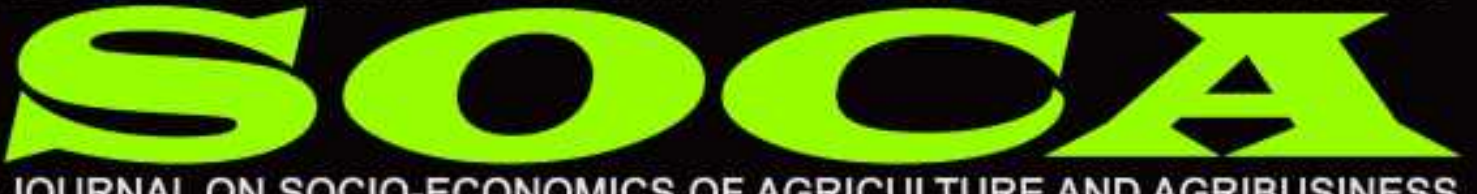

JOURNAL ON SOCIO-ECONOMICS OF AGRICULTURE AND AGRIBUSINESS

\title{
PRODUKSI DAN PENDAPATAN USAHATANI PADI DI LAHAN RAWA LEBAK KABUPATEN OGAN KOMERING ILIR SUMATERA SELATAN
}

\author{
Suparwoto \\ Balai Pengkajian Teknologi Pertanian Sumatera Selatan \\ J1. Kol. H. Burlian KM 6 no. 83 Km 6 Palembang \\ Email: suparwoto11@gmail.com \\ HP: 082175323647
}

\begin{abstract}
ABSTRAK
Kegiatan dilaksanakan pada di Desa Awal Terusan, Kecamatan Sirah Pulau Padang, Kabupaten Ogan Komering Ilir, Sumatera Selatan dimulai pada musim kemarau 2017. Tujuan kegiatan untuk mengetahui produksi dan pendapatan usahatani padi varietas unggul di lahan rawa lebak Varietas yang digunakan yaitu: Inpari 9, Inpari 30, Inpari 33, Inpara 4 dan Mekongga, IR 42 sebagai pembanding dilaksanakan seluas satu hektar. Jarak tanam legowo 2:1 $(50 \mathrm{~cm}$ x25 cm x 12,5 $\mathrm{cm})$. Dosis pupuk $150 \mathrm{~kg} / \mathrm{ha}$ urea, $100 \mathrm{~kg} / \mathrm{ha}$ TSP dan $100 \mathrm{~kg} / \mathrm{ha} \mathrm{KCL}$ diberikan secara disebar. Metoda yang digunakan adalah pengamatan langsung di lapangan (observasi) terhadap varietas unggul yang diperagakan. Data yang diperoleh disusun secara tabulasi dan dianalisis dengan uji statistik yaitu uji kesamaan nilai tengah (uji-t) dan dan analisis usahatani. Hasil menunjukkan bahwa tinggi tanaman Inpari 9, Inpari 30, Inpari 33 dan Inpara 4 tergolong rendah sehingga sesuai untuk di tanam di lahan rawa lebak. Produktivitas Inpari 9 dan Inpara 4 lebih tinggi dari Mekongga dan IR 42, yaitu 7,6-7,7 ton GKP/ha, sedangkan produktivitas Inpari 33 dan Inpari 30 yaitu 3,8-4,4 ton GKP/ha lebih rendah dari Mekongga dan IR 42. Secara ekonomis usahatani padi dengan menggunakan semua varietas menguntungkan kecuali Inpari 33, tetapi pendapatan Inpari 9 dan Inpara 4 lebih besar dari varietas lainnya dengan nilai $\mathrm{BC}$ ratio 3,5 dan 2,5.
\end{abstract}

Kata kunci: Pendapatan, produksi, rawa lebak, varietas padi

\section{PRODUCTION AND RICE FARMING INCOME IN THE LEBAK LANDS OGAN KOMERING ILIR DISTRICT, SOUTH SUMATERA}

\section{ABSTRACT}

The activity was carried out in the Awal Terusan village, Sirah Pulau Padang Subdistrict, Ogan Komering Ilir Regency, South Sumatra starting in the dry season of 2017. The purpose of the activity is to find out the production and income of superior varieties of rice farming on lebak land. The varieties used are: Inpari 9, Inpari 30, 
Inpari 33, Inpara 4 and Mekongga, IR 42 as a comparison of one hectare. Spacing of Legowo 2: $1(50 \mathrm{~cm} \times 25 \mathrm{~cm} \times 12.5 \mathrm{~cm})$. The dosage of fertilizer is $150 \mathrm{~kg} / \mathrm{ha}$ urea, $100 \mathrm{~kg} / \mathrm{ha} T S P$ and $100 \mathrm{~kg} / \mathrm{ha} \mathrm{KCL}$ are distributed. The method used is direct observation on the field of superior varieties exhibited. The data obtained was arranged in tabulation and analyzed by statistical tests, namely the test of the mean value (test-t) and farm analysis. The results showed that the plant height of Inpari 9, Inpari 30, Inpari 33 and Inpara 4 were low so that they were suitable for planting on lebak lands. Productivity of Inpari 9 and Inpara 4 are higher than Mekongga and IR 42, which are 7.6-7.7 tons GKP / ha, while the productivity of Inpari 33 and Inpari 30 is 3.8-4.4 tons GKP / ha lower than Mekongga and IR 42. Economically rice farming using all varieties is profitable except Inpari 33, but income Inpari 9 and Inpara 4 are greater than other varieties with $B C$ ratio 3.5 and 2.5 .

Keywords: Income, lebak lands, production, rice varieties

\section{PENDAHULUAN}

Prioritas pembangunan nasional yaitu penyediaan beras dalam jumlah yang besar dan harga terjangkau karena beras merupakan makanan pokok untuk lebih dari 95\% penduduk Indonesia, selain itu juga sebagai penyedia lapangan kerja bagi sekitar 20 juta rumah tangga petani di pedesaan (Makarim dan Ikhwani, 2014).

Salah satu agroekosistem lahan sawah yang dapat memberikan sumbangan dalam meningkatkan produksi beras di Sumatera Selatan (Sumsel), yaitu lahan rawa lebak sekitar 2,98 juta ha, sedangkan yang sudah dimanfaatkan sekitar 368.690 ha. Maka luas areal rawa lebak yang belum dimanfaatkan seluas 2,61 juta ha (Puslitbangtanak, 2002 dalam Waluyo et al., 2010). Sehingga dengan luasan tersebut maka Sumatera Selatan mempunyai potensi untuk mengembangkan tanaman pangan khusunya beras.

Produktivitas padi lahan rawa lebak masih tergolong rendah yaitu berkisar 2,7-3 ton/ha, bila dibandingkan dengan potensi hasil dari beberapa varietas unggul baru padi yaitu 6-8 ton/ha (Jamil et al.,
2016). Dikemukakan oleh Abdullah et al. (2008), bahwa penyebab rendahnya produksi padi tersebut diantaranya telah tercapainya potensi hasil optimum dari varietas unggul baru (VUB) yang ditanam petani atau penggunaan benih yang tidak bermutu dan kebiasaan petani menggunakan benih dari tanaman sendiri yang tumbuhnya tidak seragam lagi serta benih bermutu/berlabel sulit didapat tepat pada waktuya (Endrizal et al. 2003 dalam Jumakir et al., 2015).

Badan Litbang Pertanian telah banyak menghasilkan varietas unggul baru. Pembentukan varietas ini diarahkan pada peningkatan potensi hasil, toleran terhadap cekaman kekeringan, kebanjiran, dan hama/penyakit utama padi. Menurut Suprihatno et al., (2011), varietas unggul baru merupakan salah satu teknologi inovatif yang handal untuk meningkatkan produktivitas padi, baik melalui peningkatan potensi atau daya hasil tanaman maupun toleran atau tahan terhadap cekaman biotik dan abiotik. Varietas unggul mempunyai gen ketahanan yang terbatas, bila terjadi perubahan strain di lapangan ketahanan akan patah dan varietas yang tadinya tahan memberikan respon peka terhadap wabah dari 
strain yang muncul. Oleh karena itu diperlukan varietas unggul baru untuk menggantikan varietas unggul tersebut. Balai Besar Penelitian Tanaman Padi telah melepas berbagai varietas unggul baru padi spesifik lokasi untuk semua agroekosistem budidaya padi sejak tahun 2007 hingga 2013, diantaranya Inpari untuk ditanam di lahan sawah irigasi, Inpara untuk ditanam di lahan rawa, dan Inpago untuk ditanam di lahan kering (Mejaya et al., 2014). Dikemukakan oleh Mugiono et al., (2010) bahwa teknologi varietas lebih aman, dan lebih ramah lingkungan serta murah harganya bagi petani. Oleh karena itu, varietas merupakan salah satu teknologi unggulan dan utama dalam upaya peningkatan produksi dan nilai ekonomi padi. Penanaman varietas padi yang adaptif pada lahan sawah rawa lebak adalah salah satu upaya penting yang perlu ditempuh sehingga produktivitasnya lebih tinggi, tahan terhadap hama dan penyakit utama dan mempunyai kualitas beras yang baik.

Berdasarkan hasil pengkajian bahwa varietas inpari diketahui dapat beradaptasi pada agroekosistem rawa lebak dan bahkan menjadi varietas yang direkomendasikan untuk mengantisipasi adanya dampak perubahan iklim. Penanaman VUB Inpari dan Inpara telah dilakukan di lahan rawa lebak diantaranya Kabupaten Musi Banyuasin, Banyuasin, Ogan Komering Ilir dan Ogan Ilir. Pada tahun 2010 dikenalkan empat VUB Inpari di Kabupaten Ogan Ilir yakni Inpari 1, Inpari 3, Inpari 4 dan Inpari 13 dengan produktivitas berturut-turut 5,33 ton/ha, 5,65 ton/ha, 5,33 ton/ha dan 4,75 ton/ha (Soehendi dan Syahri, 2013).
Hasil kajian sebelumnya bahwa inpari dapat beradaptasi di lahan rawa lebak dengan hasil yang lebih tinggi dibandingkan dengan existing petani maka perlu diperkenalkan varietas inpari lainnya dan inpara, sehingga varietas inpari dan inpara dapat berkembang di masyarakat. Tujuan kegiatan untuk mengetahui produksi dan pendapatan usahatani padi varietas unggul di lahan rawa lebak.

\section{METODE PENELITIAN}

Kegiatan dilaksanakan di Desa Awal Terusan, Kecamatan Sirah Pulau Padang, Kabupaten Ogan Komering Ilir, Sumatera Selatan pada musim kemarau 2017. Bahan yang dibutuhkan antara lain: benih padi kelas SS (varietas Inpari 9, Inpari 30, Inpari 33 dan Inpara 4) berlabel ungu dan pembanding Mekongga dan IR 42, pupuk Urea, SP-36, $\mathrm{KCl}$, pestisida, herbisida dan terpal. Selain itu alat yang dibutuhkan antara lain: hand traktor, meteran, timbangan, parang, cangkul, sprayer. Jumlah varietas unggul yang dikaji 4 varietas label ungu/benih pokok (SS) yaitu Inpari 9, Inpari 30 Inpari 33, dan Inpara 4 seluas 1 hektar. Jarak tanam legowo 2:1 (50 cmx $25 \mathrm{cmx} \mathrm{12,5} \mathrm{cm).} \mathrm{Takaran}$ pupuk tunggal Urea, SP-36 dan $\mathrm{KCl}$ yang digunakan berdasarkan alat PUTS sehingga takaran pupuk per hektar adalah $150 \mathrm{~kg}$ Urea, $100 \mathrm{~kg}$ SP36 dan $100 \mathrm{~kg} \mathrm{KCl}$. Pada umur tanaman lebih kurang 7-10 hari setelah tanam diberikan pupuk $75 \mathrm{~kg}$ urea dan pupuk SP-36 dan $\mathrm{KCl}$ diberikan seluruhnya yaitu $100 \mathrm{~kg}$ SP36 dan $100 \mathrm{~kg} \mathrm{KCl} / \mathrm{ha}$. Kemudian pada umur tanaman 30-35 hari setelah tanam diberikan pupuk urea sisanya yaitu $75 \mathrm{~kg} / \mathrm{ha}$. Data yang dikumpulkan meliputi : aspek agronomis dan aspek finansial 
usahatani. Aspek agronomis terdiri dari: tinggi tanaman, jumlah anakan produktif, jumlah gabah per malai, jumlah gabah isi per malai dan produksi. Aspek finansial usahatani terdiri dari: input dan output usahatani. Metoda yang digunakan adalah pengamatan langsung di lapangan (observasi) terhadap varietas unggul yang diperagakan. Data yang diperoleh disusun secara tabulasi dan dianalisis dengan uji statistik yaitu uji kesamaan nilai tengah (uji-t) dengan perangkat lunak SPSS 11 dan analisis usahatani yaitu analisis penerimaan, pendapatan, dan analisis imbangan pendapatan atas biaya $(\mathrm{B} / \mathrm{C})($ Malian, 2004):

$$
\text { B C ratio = } \frac{(\text { RAVC) }}{-------------}
$$

Dimana:

$\mathrm{BC}$ ratio = Nisbah pendapatan terhadap biaya

$\mathrm{P} \quad \quad=$ Harga jual padi $(\mathrm{Rp} / \mathrm{kg})$

TVC = Biaya total $(\mathrm{Rp} / \mathrm{ha} / \mathrm{musim})$

RAVC $=(\mathrm{Q} \times \mathrm{P})-\mathrm{TVC}$

$\mathrm{Q}=$ Total produksi padi $(\mathrm{kg} / \mathrm{ha} / \mathrm{musim})$

Dengan keputusan:

BC Ratio > 1, usahatani secara ekonomi menguntungkan

$\mathrm{BC}$ Ratio $=1$, usahatani secara ekonomi berada pada titik impas

$\mathrm{BC}$ Ratio $<1$, usahatani secara ekonomi tidak menguntungkan

\section{HASIL DAN PEMBAHASAN}

Analisis statistik menunjukkan bahwa tinggi tanaman dari Inpari 9, Inpari 30, dan Inpara 4 tidak berbeda nyata dengan Mekongga dan IR 42 sebagai pembanding tetapi berbeda sangat nyata dengan Inpari 33 karena mempunyai pertumbuhan tinggi tanaman yang terendah yaitu 94,7 $\mathrm{cm}$. Sedangkan varietas pembanding Mekongga dan IR 42 mempunyai tinggi tanaman tidak berbeda nyata dimana Mekongga lebih rendah yaitu 98,5 cm. Tinggi tanaman varietas yang dikaji bervariasi dari 94,7 cm-101,5 cm, dimana tanaman terendah Inpari 33 yaitu 94,7 $\mathrm{cm}$ dan tertinggi tanaman IR 42 yaitu $101,5 \mathrm{~cm}$ (kontrol). Varietas tersebut menunjukkan tidak ada yang rebah (Tabel 1). Karakter tinggi tanaman merupakan salah satu karakter agronomi yang harus diperhatikan terutama di lahan rawa lebak, karena lahan rawa lebak mempunyai struktur tanah amorf dan terdapat lumpur yang dalam, akibatnya daya topang tanah rendah sehingga tanaman yang mempunyai postur tinggi akan mudah rebah (Bakri et al,.2006). 
Tabel 1. Keragaan tinggi tanaman saat panen padi pada demplot di Desa Awal Terusan Kab.OKI, MK 2017

\begin{tabular}{|c|c|c|c|c|c|c|}
\hline \multirow[t]{2}{*}{ Varietas } & \multirow{2}{*}{$\begin{array}{l}\text { Rata- } \\
\text { rata }\end{array}$} & \multicolumn{5}{|c|}{ Nilai Beda } \\
\hline & & Inpari 9 & Inpari 30 & Inpari 33 & Inpara 4 & Mekongga \\
\hline Inpari 9 & 97,9 & - & & & & \\
\hline Inpari 30 & 98,3 & tn & - & & & \\
\hline Inpari 33 & 94,7 & tn & $* *$ & - & & \\
\hline Inpara 4 & 100,8 & $\operatorname{tn}$ & tn & ** & - & \\
\hline Mekongga & 98,5 & tn & tn & $* *$ & tn & - \\
\hline IR 42 & 101,5 & tn & $\operatorname{tn}$ & $* *$ & tn & tn \\
\hline Rata-rata & 98,6 & & & & & \\
\hline eterangan & & $\begin{array}{l}\text { beda sa } \\
k \text { berb }\end{array}$ & $\begin{array}{l}\text { nyata }(\mathrm{P} \\
\text { nyata(Pro }\end{array}$ & $\begin{array}{l}\text { babilitas } \\
\text { abilitas }>0\end{array}$ & $\begin{array}{l}0.01) \\
05)\end{array}$ & \\
\hline
\end{tabular}

Variabel jumlah anakan produktif merupakan salah satu komponen pendukung dalam meningkatkan produksi gabah. Banyak sedikitnya anakan produktif suatu varietas sangat dipengaruhi oleh faktor keturunan, umur bibit, dan cekaman lingkungan dimana varietas tersebut ditanam. Secara statistik terdapat perbedaan nyata dan tidak nyata antar varietas terhadap jumlah anakan produktif/rumpun (Tabel 2).

Tabel 2. Keragaan jumlah anakan produktif padi pada demplot di Desa Awal Terusan Kab. OKI, MK 2017

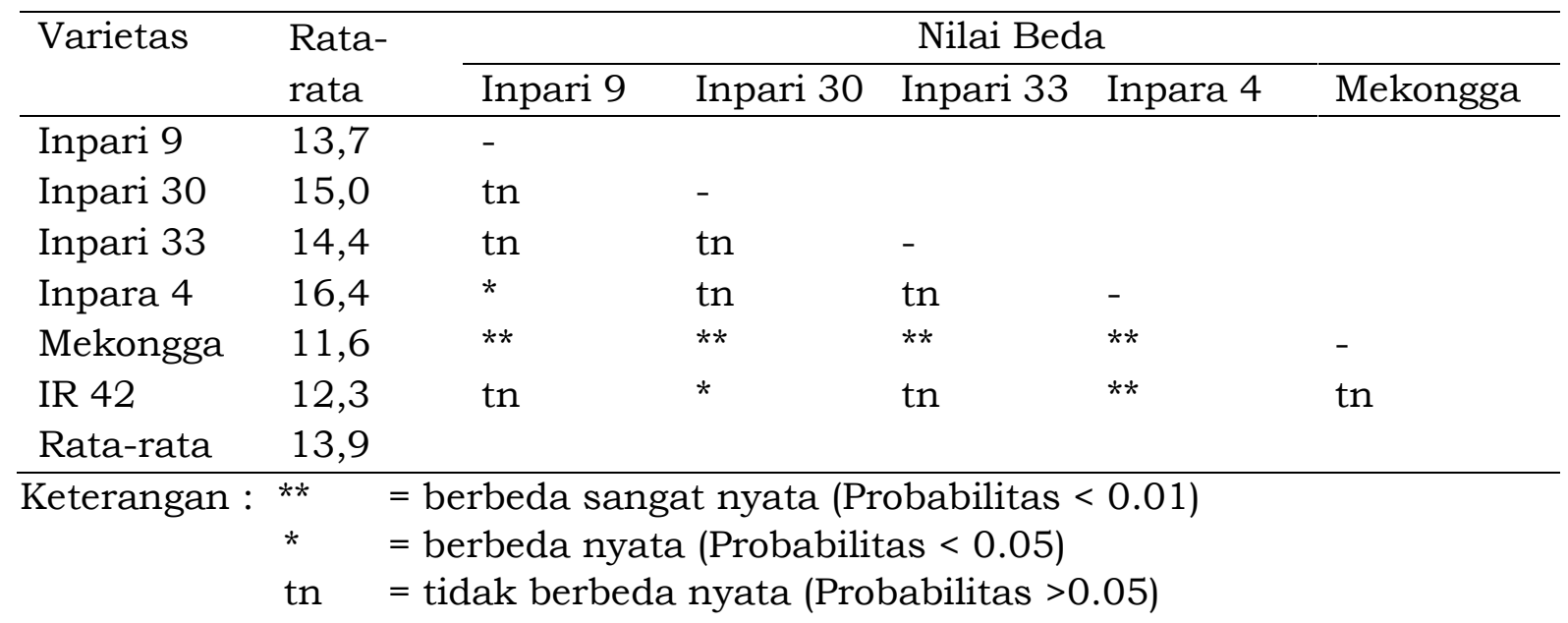

Pada Tabel 2, menunjukkan bahwa hasil analisis statistik dari jumlah anakan produktif dari Inpari 9, Inpari 30, Inpari 33 dan Inpara 4 berbeda sangat nyata dengan Mekongga karena Mekongga mempunyai anakan produktif paling sedikit yaitu 11,6 batang/rumpun sedangkan Inpari 9 dan Inpari 33 tidak berbeda nyata dengan IR 42 tetapi berbeda sangat nyata dengan Inpara 4 karena Inpara 4 mempunyai anakan produktif terbanyak yaitu 16,4 batang/rumpun. Kemudian antara varietas pembanding Mekongga dan IR 42 tidak berbeda nyata terhadap jumlah anakan produktif/rumpun. Keragaan jumlah anakan produktif/rumpun dari varietas yang dikaji bervariasi dari 11,6-16,4 batang/rumpun. Jumlah anakan terbanyak ditunjukkan oleh Inpara 4 yaitu 16,4 batang/rumpun dan 
jumlah anakan sedikit yaitu 11,6 batang/rumpun oleh Mekongga.

Tinggi dan rendahnya produksi gabah suatu varietas juga ditentukan oleh jumlah gabah/malai (gabah bernas dan gabah hampa) dan banyak sedikitnya gabah per malai dipengaruhi oleh sifat genetik (keturunan) dan cekaman lingkungan abiotik dan biotik. Sehingga jumlah gabah/malai antar varietas bervariasi dari 120,1-150,3 butir (Tabel 3).

Tabel 3. Keragaan jumlah gabah per malai padi pada demplot di Desa Awal Terusan Kab.OKI, MK 2017

\begin{tabular}{|c|c|c|c|c|c|c|}
\hline \multirow[t]{2}{*}{ Varietas } & \multirow{2}{*}{$\begin{array}{l}\text { Rata- } \\
\text { rata }\end{array}$} & \multicolumn{5}{|c|}{ Nilai Beda } \\
\hline & & Inpari 9 & Inpari 30 & Inpari 33 & Inpara 4 & Mekongga \\
\hline Inpari 9 & 156,7 & - & & & & \\
\hline Inpari 30 & 140,9 & $\operatorname{tn}$ & - & & & \\
\hline Inpari 33 & 138,4 & tn & $\operatorname{tn}$ & - & & \\
\hline Inpara 4 & 150,3 & $\operatorname{tn}$ & $\operatorname{tn}$ & $\operatorname{tn}$ & - & \\
\hline Mekongga & 120,1 & $* *$ & $* *$ & $\operatorname{tn}$ & $* *$ & - \\
\hline IR 42 & 131,8 & * & $\operatorname{tn}$ & $\operatorname{tn}$ & $\operatorname{tn}$ & $\operatorname{tn}$ \\
\hline Rata-rata & 139.7 & & & & & \\
\hline Keterangan : & $\begin{array}{ll}* * & = \\
* & = \\
\text { tn } & =\end{array}$ & $\begin{array}{l}\text { rbeda sar } \\
\text { rbeda ny } \\
\text { ak berbe }\end{array}$ & $\begin{array}{l}\text { t nyata }(\mathrm{Pr} \\
\text { (Probabili } \\
\text { nyata (Pro }\end{array}$ & $\begin{array}{l}\text { obabilitas } \\
\text { as }<0.05 \text { ) } \\
\text { abilitas }>0\end{array}$ & $\begin{array}{l}0.01) \\
05)\end{array}$ & \\
\hline
\end{tabular}

Keragaan jumlah gabah per malai dari Inpari 9, Inpari 30, Inpari 33 dan Inpara 4 yang terdapat pada tabel 3, setelah dianalisis secara statistik bahwa Inpari 30, Inpari 33 dan Inpara 4 tidak berbeda nyata dengan IR 42 tetapi berbeda nyata dengan Inpari 9, sedangkan Inpari 9, Inpari 30 dan Inpara 4 berbeda sangat nyata dengan Mekongga karena Mekongga mempunyai jumlah gabah per malai paling sedikit yaitu 120,1 butir tetapi tidak berbeda nyata dengan Inpari 33. Jumlah gabah terbanyak dicapai oleh Inpari 9 yaitu
156,7 butir tidak berbeda nyata dengan Inpari 30, Inpari 33 dan Inpara 4, sedang jumlah gabah antara varietas pembanding Mekongga dan IR 42 tidak berbeda nyata, tetapi IR 42 lebih baik. Jumlah gabah isi (bernas)/malai antar varietas bervariasi dari 94,5-118,5 butir dimana gabah bernas yang sedikit 94,5 butir ditunjukkan oleh Mekongga dan terbanyak 118,5 butir dicapai oleh Inpara 4. Variabel ini juga mendukung untuk meningkatkan produksi gabah (Tabel 4). 
Tabel 4. Keragaan jumlah gabah isi per malai padi pada demplot di Desa Awal Terusan Kab.OKI, MK 2017

\begin{tabular}{|c|c|c|c|c|c|c|}
\hline \multirow[t]{2}{*}{ Varietas } & \multirow{2}{*}{$\begin{array}{l}\text { Rata- } \\
\text { rata }\end{array}$} & \multicolumn{5}{|c|}{ Nilai Beda } \\
\hline & & Inpari 9 & Inpari 30 & Inpari 33 & Inpara 4 & Mekongga \\
\hline Inpari 9 & 107,7 & - & & & & \\
\hline Inpari 30 & 110,6 & $\operatorname{tn}$ & - & & & \\
\hline Inpari 33 & 104,6 & tn & tn & - & & \\
\hline Inpara 4 & 118,5 & tn & tn & tn & - & \\
\hline Mekongga & 94,5 & * & $* *$ & $\operatorname{tn}$ & $* *$ & - \\
\hline IR 42 & 113,2 & tn & tn & tn & tn & $* *$ \\
\hline Rata-rata & 108,2 & & & & & \\
\hline Keterangan & $\begin{array}{l}* * \\
* \\
\text { tn }\end{array}$ & $\begin{array}{l}\text { rbeda sar } \\
\text { rbeda ny } \\
\text { ak berbe }\end{array}$ & $\begin{array}{l}\text { t nyata }(\mathrm{P} \\
\text { (Probabili } \\
\text { nyata (Pro }\end{array}$ & $\begin{array}{l}\text { babilitas } \\
\text { as }<0.05 \text { ) } \\
\text { abilitas }>(\end{array}$ & $\begin{array}{l}0.01) \\
.05)\end{array}$ & \\
\hline
\end{tabular}

Hasil analisis statistik menunjukkan bahwa jumlah gabah isi per malai dari Inpari 9, Inpari 30, Inpari 33 dan Inpara 4 tidak berbeda nyata dengan varietas pembanding IR 42. Selanjutnya jumlah gabah isi dari Inpari 30 dan Inpara 4 berbeda sangat nyata dan Inpari 9 berbeda nyata dengan Mekongga (94,5 butir) yang mempunyai gabah isi yang paling sedikit. Sedangkan gabah isi per malai terbanyak yaitu 118,5 butir oleh Inpara 4. Kemudian jumlah gabah isi antara Mekongga dengan IR 42 sangat berbeda nyata dimana IR 42 mempunyai gabah isi lebih banyak dari Mekongga (Tabel 4).

Tabel 5. Keragaan produksi gabah (ton GKP/ha) padi pada demplot di Desa Awal Terusan Kab.OKI, MK 2017

\begin{tabular}{|c|c|c|c|c|c|c|}
\hline \multirow[t]{2}{*}{ Varietas } & \multirow{2}{*}{$\begin{array}{l}\text { Rata- } \\
\text { rata }\end{array}$} & \multicolumn{5}{|c|}{ Nilai Beda } \\
\hline & & Inpari 9 & Inpari 30 & Inpari 33 & Inpara 4 & Mekongga \\
\hline Inpari 9 & 7,7 & - & & & & \\
\hline Inpari 30 & 4,4 & $* *$ & - & & & \\
\hline Inpari 33 & 3,8 & $* *$ & tn & - & & \\
\hline Inpara 4 & 7,6 & tn & $* *$ & ** & - & \\
\hline Mekongga & 6,1 & * & $*$ & $* *$ & tn & - \\
\hline IR 42 & 4,6 & $* *$ & tn & tn & * & * \\
\hline Rata-rata & 5,7 & & & & & \\
\hline Keterangan : & $\begin{array}{l}* * \\
* \\
\text { tn }\end{array}$ & $\begin{array}{l}\text { rbeda sar } \\
\text { rbeda ny } \\
\text { lak berbe }\end{array}$ & $\begin{array}{l}\text { t nyata }(\mathrm{Pr} \\
\text { (Probabili } \\
\text { nyata (Pro }\end{array}$ & $\begin{array}{l}\text { babilitas } \\
\text { as }<0.05 \text { ) } \\
\text { abilitas }>0\end{array}$ & $\begin{array}{l}0.01) \\
.05)\end{array}$ & \\
\hline
\end{tabular}

Hasil analisis statistik produktivitas dari Inpari 9 dan Inpari 30 berbeda nyata dan Inpari 33 berbeda sangat nyata serta Inpara 4 berbeda tidak nyata dengan Mekongga (6,1 ton GKP/ha), sedangkan Inpari 9 berbeda sangat nyata, Inpari 30 dan
Inpari 33 berbeda tidak nyata dan Inpara 4 berbeda nyata dengan IR 42 (4,6 ton GKP/ha). Kemudian produktivitas antar varietas pembanding Mekongga dan IR 42 berbeda nyata. Inpari 9 dan Inpara 4 mempunyai produktivitas gabah lebih 
tinggi dari Mekongga, IR 42, Inpari 33 dan Inpari 30 yaitu 7,7 dan 7,6 ton GKP/ha (Tabel 5). Deskripsi hasil dari Inpari 9 yaitu 6,4 ton $\mathrm{gkg} / \mathrm{ha}$ dan potensi hasil 9,3 ton GKP/ha sedangkan Inpara 4 yaitu 4,7 ton GKP/ha dengan potensi hasil 7,6 ton GKP/ha. Produktivitas yang dicapai oleh Inpari 9 dan Inpara 4 sesuai dengan deskripsinya sehingga varietas tersebut dapat direkomendasikan untuk dikembangkan di lahan rawa lebak tengahan. Perbedaan hasil gabah disebabkan oleh perbedaan sifat dari masing-masing varietas dan kondisi lingkungan tempat tumbuhnya (Ramli, 1993) dalam Waluyo dan Suparwoto (2016). Selanjutnya Taslim et al., (1993) dalam Handoko et al., (2017) bahwa hasil tanaman padi ditentukan oleh beberapa komponen hasil penting seperti: jumlah malai per rumpun, jumlah gabah per malai, persentase gabah isi dan berat 1000 biji.

\section{Analisis Usahatani}

Tabel 6. Analisis usahatani padi varietas unggul di sawah rawa lebak pada luasan 1 ha di Desa Awal Terusan di Kabupaten OKI Tahun 2017

\begin{tabular}{|c|c|c|c|c|c|c|}
\hline \multirow{2}{*}{ Uraian } & \multicolumn{6}{|c|}{ Nilai (Rp) } \\
\hline & Inpari 9 & Inpari 30 & Inpari 33 & Inpara 4 & Mekongga & IR 42 \\
\hline Biaya Saprodi (Rp) & 4.260 .000 & 4.260 .000 & 4.260 .000 & 4.260 .000 & 4.260 .000 & 4.260 .000 \\
\hline $\begin{array}{l}\text { Biaya Tenaga kerja } \\
\text { (Rp) }\end{array}$ & 3.320 .000 & 3.320 .000 & 3.320 .000 & 3.320 .000 & 3.320 .000 & 3.320 .000 \\
\hline $\begin{array}{l}\text { Total biaya } \\
\text { produksi } \\
\text { (Rp/ha/musim) }\end{array}$ & 7.580 .000 & 7.580 .000 & 7.580 .000 & 7.580 .000 & 7.580 .000 & 7.580 .000 \\
\hline $\begin{array}{l}\text { Produksi (kg } \\
\text { gkp/ha) }\end{array}$ & 7,7 & 4,4 & 3,8 & 7,6 & 6,1 & 4,6 \\
\hline $\begin{array}{l}\text { Produksi (kg } \\
\text { gkp/ha) setelah } \\
\text { dipotong bawon } \\
\text { 10:2 }\end{array}$ & 6416 & 3666 & 3166 & 6333 & 5083 & 3833 \\
\hline $\begin{array}{l}\text { Penerimaan } \\
\text { (Rp/ha/musim) }\end{array}$ & 26.947 .200 & 15.397 .200 & 13.297 .200 & 26.598 .600 & 21.348 .600 & 16.098 .600 \\
\hline $\begin{array}{l}\text { Pendapatan } \\
\text { (Rp/ha/musim) }\end{array}$ & 19.367 .200 & 7.817 .200 & 5.717 .200 & 19.018 .600 & 13.768 .600 & 8.518 .600 \\
\hline $\mathrm{BC}$ ratio & 3,5 & 1,0 & 0,7 & 2,5 & 1,8 & 1,1 \\
\hline
\end{tabular}

Keterangan: Harga GKP Rp 4200/kg

Sumber: data diolah, 2017

Varietas yang ditanam yaitu Inpari 9, Inpari 30, Inpari 33 dan Inpara 4 serta Mekongga dan IR 42 sebagai pembanding seluas satu hektar di Desa Awal Terusan Kabupaten Ogan Komering Ilir. Total Biaya produksi semua varietas sama mencapai Rp 7.580.000/ha/musim tidak termasuk biaya panen dan merontok karena biaya panen dan merontok diambil dari borongan sistem bawon 10:2 dimana 10 bagian pemilik dan 2 bagian biaya upah panen dan merontok. Gabah dijual dalam kondisi kering panen dengan harga Rp 4200/kg. Penerimaan yang terbesar diperoleh dari usahatani padi Inpari 9, dan Inpara 4 yaitu $\mathrm{Rp}$ 26.947.200/ha/musim, dan Rp 26.598.600/ha/musim dibandingkan Mekongga dan IR 42, maka pendapatan rata-rata selama satu kali musim tanam usahatani padi dari Inpari 9, dan Inpara 4 berturut-turut 
Rp19.367.200/ha/musim, $\quad$ Rp 19.018.600/ha/musim dengan BC ratio 3,5 dan 2,5. Secara ekonomis usahatani padi Inpari 9, Inpara 4, Inpari 30, Mekongga dan IR 42 menguntungkan karena nilai $\mathrm{BC}$ ratio lebih dari satu, kecuali Inpari 33 (Tabel 6).

\section{KESIMPULAN}

Produksi dari Inpari 9, Inpari 30, Inpari 33, Inpara 4, Mekongga dan IR 42 bervariasi dari 3,8-7,7 ton GKP/ha. Produksi gabah Inpari 9 dan Inpara 4 lebih tinggi dari Mekongga, dan IR 42, yaitu 7,7 dan 7,6 ton GKP/ha. Secara ekonomis maka pendapatan usahatani padi Inpari 9, dan Inpara 4 lebih besar dari varietas lainnya dengan nilai $\mathrm{BC}$ ratio 3,5 dan 2,5. Semua varietas layak dikembangkan dan menguntungkan kecuali Inpari 33.

\section{UCAPAN TERIMA KASIH}

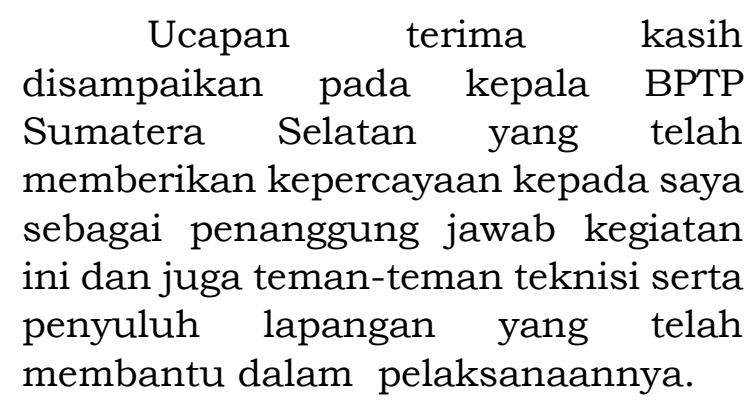

\section{DAFTAR PUSTAKA}

Abdullah, B., T. Soewito, dan Sularjo. 2008. Perkembangan dan prospek perakitan padi tipe baru di Indonesia. Jurnal Litbangtan 27(1): 1-8.

Bakri dan R.H. Susanto. 2006. Keragaan produksi beberapa varietas padi hasil mutasi radiasi di daerah rawa lebak di Kecamatan Rambutan Musi Banyuasin, Sumatera Selatan. Jurnal Tanaman Tropika 9 (1) : 24-29.
Handoko, S, Y.Farmanta dan Adri. $2017 . \quad$ Peningkatan produktivitas padi sawah melalui introduksi varietas unggul baru di Kabupaten Tanjung Jabung Timur Jambi. Prosiding Seminar Nasional Pengkajian Teknologi Spesifik Lokasi Komoditas Tanaman Pangan (hlm. 96-100). 8 November 2016. Bengkulu: BPTP Bengkulu Badan Litbang Pertanian.

Jamil, A, Satoto, P. Sasmita, Y. Baliadi, A. Guswara dan Suhama. 2016. Deskripsi Varietas Padi. Balai Besar Penelitian Tanaman Padi, Sukamandi.

Jumakir, Kamalia Muliyanti dan Endrizal. 2015. Penangkaran benih padi VUB Inpara 3 dan penyebarannya di lahan rawa pasang surut Jambi. Prosiding Seminar Nasional Inovasi Teknologi Padi Mendukung Pertanian Bioindustri Buku 2 (hlm 861-874). 19 Agustus 2014. Sukamandi: Balai Besar Penelitian Tanaman Padi, Badan Litbang Pertanian.

Makarim, A.K. dan Ihkwani. 2014. Perakitan dan penyesuaian teknologi budidaya untuk varietas baru padi sawah di Kabupaten Subang. Prosiding Seminar Nasional 2013. Inovasi teknologi Padi Adaptif Perubahan Iklim Global Mendukung Surplus 10 Juta ton beras tahun 2014. Buku 2 (hlm 599-610). 4-5 Juli 2013. Sukamandi: Balai Besar Penelitian Tanaman Padi Badan Litbang Pertanian.

Malian, A. Husni. 2004. Analisis ekonomi usahatani dan kelayakan finansial teknologi 
pada skala pengkajian. Pusat Penelitian dan Pengembangan Sosial Ekonomi Pertanian dan Proyek Pengkajian Teknologi Pertanian Partisipatif (The Participating Development of technology Transfer Project (PAATP). Badan Penelitian dan Pengembangan Pertanian.

Mejaya, M.J., Satoto, P. Sasmita, Y. Baliadi, A. Guswara dan Suharna. 2014. Deskripsi varietas unggul baru padi. Sukamandi. Balai Besar Penelitian Tanaman Padi Badan Litbang Pertanian.

Mugiono, Sherly Rahayu, Jeany P. Mandang. 2010. Penggunaan teknik mutasi radiasi untuk perbaikan bentuk dan umur padi varietas superwin. Prosiding Seminar Nasional Hasil Penelitian padi 2009, Buku 1 (hlm 161-170). 20 Oktober 2009. Sukamandi: Balai Besar Penelitian Tanaman Padi, Badan Litbang Pertanian.

Soehendi, R., dan Syahri. 2013. Kesesuaian Varietas Unggul Baru Padi di Sumatera Selatan. Prosiding Seminar Nasional Inovasi Teknologi Pertanian Spesifik Lokasi (hlm. 304-310). 6-7 Juni 2013. Medan: Balai Pengkajian Teknologi Pertanian Sumatera Utara, Badan Litbang Pertanian.

Suprihatno, B., A.A. Daradjat, Satoto, Suwarno, E. Lubis, Baehaki, Sudir, S.D.Indrasari, I.P.Wardana, M.J.Mejaya. 2011. Deskripsi varietas padi. Sukamandi. Balai Besar Penelitian Tanaman Padi, Badan Litbang Pertanian.

Waluyo, Suparwoto dan I.W. Supartha. 2010. Usaha padi di lahan rawa lebak Sumatera Selatan melalui pendekatan PTT. Dalam : Sarlan A, Husin M Toha dan Anischan Gani (Ed). Prosiding Seminar Nasional Hasil Penelitian Padi 2009, Buku 2 (hlm. 815-823). 20 Oktober 2009. Sukamandi: Balai Besar Penelitian Tanaman Padi, Badan Litbang Pertanian.

Waluyo dan Suparwoto. 2016. Peranan varietas padi unggul baru dalam meningkatkan produktivitas dan penghasilan petani lebak Kabupaten Ogan Ilir Sumatera Selatan. Prosiding Seminar Nasional Pertanian Terpadu dan Berkelanjutan Berbasis Sumber Daya dan Kearifan Lokal di Era Masyarakat Ekonomi ASEAN (hlm. 198-208). 4 September 2016. Palembang: Fakultas Pertanian Universitas Sriwijaya. 